Yoghurt susu biji ketapang (Terminalia catappa L) dengan variasi ..... Nanik Suhartatik, dkk.

\title{
Yoghurt susu biji ketapang (Terminalia catappa L) dengan variasi jenis starter dan lama fermentasi
}

\section{Yoghurt from tropical almond (Terminalia catappa L) milk with various type of starter culture and fermentation}

\author{
Nanik Suhartatik $^{\mathrm{a}, \star}$, Yannie Asrie Widanti ${ }^{\mathrm{a}}$, Wida Novia Lestari ${ }^{\mathrm{a}}$, \\ Yustina Wuri Wulandari ${ }^{a}$ \\ ${ }^{a}$ Fakultas Teknologi dan Industri Pangan Universitas Slamet Riyadi Surakarta \\ JI. Sumpah Pemuda No.18 Joglo, Kadipiro, Surakarta, Indonesia \\ *E-Mail: n_suhartatik@yahoo.com
}

Diterima 13 September 2019, Direvisi 28 Nopember 2019, Disetujui 28 Nopember 2019

\begin{abstract}
ABSTRAK
Biji Ketapang mengandung asam lemak tak jenuh dan protein yang tinggi. Biji ketapang berpotensi untuk dikembangkan menjadi yoghurt atau probiotik. Penelitian ini bertujuan untuk menentukan pengaruh dan karakteristik kimia dan mikrobiologi dari penggunaan jenis starter dan lama fermentasi pada yoghurt susu biji ketapang. Metode penelitian yang digunakan adalah Rancangan Acak Lengkap (RAL) dengan pola 2 faktor. Faktor pertama variasi jenis starter yaitu $S$. thermophilus (St), L. bulgaricus (Lb) dan $S$. thermophilus-L. bulgaricus (St-Lb). Faktor kedua lama fermentasi yaitu 4, 6 dan 8 jam. Analisis data menggunakan Duncan Multiple Range Test didapatkan bahwa terdapat pengaruh nyata terhadap kadar protein, gula, lemak dan total asam namun tidak berpengaruh nyata terhadap total Bakteri Asam Laktat (BAL). Kadar protein tertinggi didapat dari perlakuan Lb dengan lama fermentasi 8 jam yaitu 13,56\%, kadar gula total $23,27 \%$ pada perlakuan jenis starter St-Lb dengan lama fermentasi 8 jam, total asam 0,59\% pada perlakuan St-Lb dengan lama fermentasi 8 jam, kadar lemak paling tinggi didapatkan dari perlakuan jenis starter St dengan lama fermentasi 4 jam yaitu $0,245 \%$. Untuk menghasilkan yoghurt biji ketapang dengan kadar protein yang tinggi, maka susu biji ketapang sebaiknya difermentasi selama 8 jam menggunakan starter Lactobacillus bulgaricus. Adapun rata-rata nilai log dari total bakteri asam laktat cenderung stabil yaitu 7,35-7,75 CFU/ml.
\end{abstract}

Kata Kunci : biji ketapang, lama fermentasi, starter, yoghurt.

\section{ABSTRACT}

Tropical almond seed contain high unsaturated fatty acid and protein. It has potent to be develop into yoghurt or probiotik The aims of the research was to determine the chemical-microbiological effect of the starter type and the fermentation duration in yoghurt from tropical almond milk. The research method used factorial Completely Randomized Design (CRD). Those two factors were, the variation of starter types: Streptococcus thermophilus (St), Lactobacillus bulgaricus (Lb), and Streptococcus thermophilusLactobacillus bulgaricus (St-Lb); and the fermentation duration (4.6 and 8 hours). The analysis of the data uses Duncan Multiple Range Test; shows that there was significant effect on protein, sugar, fat, and total acid while the total LAB (Lactic Acid Bacteria) were not significantly effected by the treatments. The highest protein amount which obtained from the treatment of $L b 8$ hours fermentation process was $13.56 \%$; total sugar amount was $23.27 \%$ with the treatment of St and Lb starter types in 8 hours fermentation process; and the highest fat amount which obtained from the treatment of St starter type in 4 hours 
fermentation was $0.245 \%$. The best treatment for tropical almond yoghurt was using $L$. bulgaricus and 8 hours of fermentation. The log value average of total Lactic Acid Bacteria (LAB) was stable; about 7.35-7.75 CFU/ml.

Keywords : tropical almond, fermentation process, starter, yoghurt.

\section{PENDAHULUAN}

Ketapang (Terminalia catappa L.) adalah sejenis pohon tepi pantai yang rindang. Minyak biji ketapang mengandung asam-asam lemak seperti asam palmitat $55,5 \%$, asam oleat $23,3 \%$, asam linoleat $7,6 \%$, asam stearat $6,3 \%$ dan asam miristat. Biji ketapang kering ini juga mengandung protein $25,3 \%$, serat $11,75 \%$ dan karbohidrat 5,8\% serta mineral seperti kalsium, magnesium, kalium dan natrium (Maghfiroh, Wijaya, Sa"adah, Valla, \& Romadhon, 2014). Biji ketapang dipilih sebagai bahan dasar pembuatan yoghurt karena kadar protein dan lemaknya yang tinggi. Kandungan asam lemak tidak jenuh yang ada dalam biji ketapang berpotensi untuk dikembangkan sebagai pangan fungsional. Biji ketapang telah dikembangkan sebagai bahan dasar pembuatan tempe (Sholeha, 2018); tahu (Budi, 2016); digunakan sebagai bahan tambahan dalam pembuatan sabun (Widyaningsih, Chasani, Diastuti, \& Fredyono, 2018), atau sebagai bahan pangan yang mempunyai aktivitas anti hiperglikemi (Sofawati, 2012). Sejauh ini, belum dijumpai penelitian yang menggunakan biji ketapang sebagai bahan dasar dalam proses pembuatan yoghurt.

Yoghurt merupakan minuman hasil fermentasi susu dengan menggunakan starter bakteri asam laktat. Starter yang biasa digunakan dalam fermentasi yoghurt adalah $S$. thermophilus, $L$ acidophilus, $L$. bulgaricus, Bifidobacteria, L. plantarum, ataupun campuran antara beberapa bakteri. Jenis starter akan mempengaruhi kualitas yoghurt yang dihasilkan. Selain itu, bahan baku yang merupakan nutrisi bagi pertumbuhan mikrobia juga sangat berperan penting dalam fermentasi yoghurt. Penelitian terdahulu menunjukkan bahwa yoghurt bisa dibuat dari susu kambing (Zain, 2017), kedelai hitam (Utaminingrum, 2011), wijen (Suhartatik, Widanti, \& Anwar, 2018) dan jagung manis
(Sayuti, Wulandari, \& Sari, 2013). Pada umumnya yoghurt diproduksi menggunakan bahan dasar susu sapi (Jaya, Kusumahadi, \& Amertaningtyas, 2011). Penggunaan bahan dasar ini membuat yoghurt bernilai jual tinggi di pasaran, sehingga tidak semua lapisan masyarakat dapat mengkonsumsinya. Oleh karena itu, perlu dimanfaatkan bahan dasar lain dalam pembuatan yoghurt seperti biji ketapang.

Pembuatan yoghurt dilakukan dengan proses fermentasi yang memanfaatkan bakteri asam laktat dari golongan $L$. bulgaricus dan S. thermophilus. Golongan $S$. thermophilus ini berkembang biak lebih cepat sehingga menghasilkan asam dan $\mathrm{CO}_{2}$ kemudian merangsang pertumbuhan bakteri L. bulgaricus. Aktivitas proteolitik dari bakteri $L$. bulgaricus dapat memproduksi peptida stimulan dan asam amino yang dipakai oleh $S$. thermophilus. Bakteri asam laktat ini bertanggung jawab dalam pembentukan tekstur dan juga rasa pada yoghurt (Ginting \& Pasaribu, 2005).

Yoghurt biji ketapang merupakan produk baru sehingga belum diketahui jenis starter dan juga lama fermentasi yang berpengaruh terhadap sifat kimia dan mikrobiologi yang tepat pada produk ini, oleh karena itu perlu dilakukan penelitian lebih lanjut. Tujuan dari pembuatan yoghurt biji ketapang ialah menentukan pengaruh penggunaan jenis starter dan lama fermentasi terhadap karakteristik kimia dan mikrobiologi yoghurt biji ketapang yang berkualitas baik.

\section{BAHAN DAN METODE}

\subsection{Alat dan Bahan}

Biji ketapang (Terminalia catappa L.) diperoleh dari daerah sekitar kampus Universitas Slamet Riyadi dan sekitarnya. Biji yang diambil adalah biji yang sudah tua ditandai dengan warna bagian luar biji yang kekuningan. Bahan pembantu seperti susu 
skim (Indoprima) dan gula (Gulaku) diperoleh dari supermarket terdekat. Kultur bakteri asam laktat $L$. bulgaricus FNCC0040 dan $S$. thermophilus FNCC0041 diperoleh dari koleksi Food and Nutrition Culture Collection (FNCC) Pusat Studi Pangan dan Gizi UGM, Yogyakarta, Indonesia. Untuk menghitung jumlah mikrobia, digunakan MRS (de Man Rogosa Sharpe, Oxoid) sedangkan bahan pembantu untuk analisis disediakan oleh Laboratorium Kimia dan Biokimia Pangan Fakultas Teknologi dan Industri Pangan UNISRI Surakarta, Indonesia dengan kualitas pro analysis (p.a).

\subsection{Tahapan Penelitian}

\subsubsection{Pembuatan kultur kerja}

Kultur $L$. bulgaricus dan $S$. thermopilus diperbanyak dengan menggunakan media MRS agar yang digoreskan dengan satu ose kultur murni, diinkubasi selama 24 jam pada suhu $37^{\circ} \mathrm{C}$. Setelah itu dapat digunakan dalam pembuatan starter atau disebut kultur kerja dan sisanya disimpan pada suhu $-4^{\circ} \mathrm{C}$ sebagai kultur stok (Kumala, Setyaningsih, \& Susilowati, 2004).

\subsubsection{Pembuatan starter}

Pembuatan starter dilakukan dengan mengambil $5 \mathrm{~mL}$ MRS Broth yang telah disterilkan kemudian diinokulasi dengan satu ose kultur kerja, diinkubasi pada suhu $37^{\circ} \mathrm{C}$ selama 48 jam sehingga didapatkan kultur cair untuk setiap bakteri. Masingmasing kultur cair diinokulasikan pada larutan susu skim sebanyak $10 \%$ yang telah steril, kemudian diinkubasi selama 24 jam sehingga didapatkan starter induk. Starter siap pakai dikerjakan dengan menginokulasikan starter siap pakai sebanyak $3 \%$ pada larutan susu skim $10 \%$ dan glukosa $3 \%$ yang diinkubasi selama 24 jam pada suhu $37^{\circ} \mathrm{C}$ (Kumala et al., 2004)

\subsubsection{Pembuatan susu biji ketapang.}

Pembuatan susu diawali dengan penyiapan bahan baku yaitu ketapang dibelah, biji dalamnya dipisahkan dari kulit luarnya. Biji ketapang dibersihkan dan dikukus selama 5 menit kemudian direndam selama 10 menit. Penggilingan dilakukan dengan air dengan perbandingan $1: 6(\mathrm{~b} / \mathrm{v})$. Penyaringan dilakukan dengan tujuan untuk memperoleh sari ketapang. Pemanasan dilakukan dengan suhu 80$85^{\circ} \mathrm{C}$ selama 3 menit (Sumarni, Mazakkar, \& Tamrin, 2017).

\subsubsection{Pembuatan yoghurt}

Susu biji ketapang dicampur dengan susu skim sebanyak $(10 \% \quad \mathrm{w} / \mathrm{v})$ dan glukosa sebanyak $(3 \% \mathrm{w} / \mathrm{v})$. Campuran homogen kemudian dipanaskan pada suhu $85^{\circ} \mathrm{C}$ selama 15 menit dan didinginkan hingga suhu $40^{\circ} \mathrm{C}$. Setelah itu dibagi ke dalam 3 erlenmeyer $100 \mathrm{ml}$, kemudian erlenmeyer I diinokulasi dengan Starter $S$. thermopilus, erlenmeyer II diinokulasikan dengan $L$. bulgaricus dan gelas erlenmeyer III diinokulasikan dengan $S$. thermophillus dan L. bulgaricus sebanyak (3\% v/v) dengan perbandingan 1:1 untuk masing masing perlakuan, kemudian diinkubasi pada suhu $37^{\circ} \mathrm{C}$ selama 4,6 , dan 8 jam (Muawanah, 2007).

\subsubsection{Cara pengumpulan data}

Analisis yang digunakan dalam penelitian ini meliputi kadar protein dengan metode Lowry-Folin (Sudarmadji, Haryono \& Suhardi, 1997), kadar lemak dengan metode Mojohnier (AOAC, 2000), total asam dengan metode Mann's acid Test (Hadiwiyoto, 1983), gula total dengan metode Nelson-Somogyi (Sudarmadji et al., 1997) dan analisis mikrobiologi meliputi penentuan jumlah bakteri pembentuk asam dengan metode Total Plate Count (Hadiwiyoto, 1983).

Rancangan percobaan menggunakan Rancangan Acak Lengkap (RAL) faktorial. Faktor pertama adalah jenis starter ( $S$. thermophiles (St), L. bulgarius (Lb), dan $S$. thermophilus- L. bulgarius, St-Lb) dan faktor kedua yaitu lama fermentasi (4, 6 dan 8 jam). Data dianalisis dengan ANOVA dilanjutkan dengan uji Duncan Multiple Range Test pada tingkat signifikasi 5\%. 


\section{HASIL DAN PEMBAHASAN}

\subsection{Analisis Proksimat Biji Ketapang}

Biji kering dijemur menghasilkan minyak berwarna kuning hingga setengah dari bobot semula. Minyak ini mengandung asam-asam lemak seperti asam palmitat $55,5 \%$, asam oleat $23,3 \%$, asam linoleat $7,6 \%$, asam stearat $6,3 \%$ dan asam miristat. Biji ketapang kering ini juga mengandung protein $25,3 \%$, serat $11,75 \%$ dan karbohidrat 5,8\% serta mineral seperti kalsium, magnesium, kalium dan natrium (Maghfiroh et. al, 2014). Kandungan gizi biji ketapang berdasarkan hasil uji proksimat dapat dilihat pada Tabel 1.

Hasil pengujian pada Tabel 1 dapat dilihat bahwa biji ketapang yang digunakan dalam penelitian ini memiliki kadar air sebesar 20,48 $\pm 0,215 \mathrm{~g} / 100 \mathrm{~g}$, abu sebesar 3,85 \pm 0,015 g/100 g, lemak 19,84 $\pm 0,030 \mathrm{~g} / 100 \mathrm{~g}$, protein ( $\mathrm{N}$ kasar) $33,38 \pm$ $0,250 \mathrm{~g} / 100 \mathrm{~g}$ dan serat kasar 13,16 \pm $0,380 \mathrm{~g} / 100 \mathrm{~g}$. Hasil peneraan kadar protein lebih besar daripada hasil penelitian yang dilakukan oleh Maghfiroh et. al (2014). Protein dalam pembuatan yoghurt sangat dibutuhkan untuk membantu meningkatkan pembentukan sel dan perkembangbiakan bakteri asam laktat $(S$. thermophilus dan $L$. bulgarius). Keberadaan lemak di dalam biji ketapang berperan dalam pembentukan emulsi (Pichot, 2010). Biji ketapang tergolong ke dalam biji-bijian yang kaya akan lemak, baik esensial maupun non esensial. Kenaikan kadar protein secara tidak langsung akan berakibat pada kenaikan jumlah sel mikrobia, yang dalam hal ini ditunjukkan pada peneraan jumlah bakteri pembentuk asam pada Tabel 2.

Tabel 1. Hasil Analisis Proksimat Biji Ketapang (g/100 g)

\begin{tabular}{cc}
\hline Parameter & Kadar $(\mathrm{g} / 100 \mathrm{~g})$ atau $\%$ \\
\hline Abu & $3,85 \pm 0,015$ \\
\hline Lemak & $19,84 \pm 0,030$ \\
\hline Protein (N kasar) & $33,38 \pm 0,250$ \\
\hline Serat Kasar & $13,16 \pm 0,380$ \\
\hline
\end{tabular}

Tabel 2. Rangkuman Hasil Analisis Kimia dan Mikrobiologi Yoghurt Susu Biji Ketapang

\begin{tabular}{|c|c|c|c|c|c|c|}
\hline $\begin{array}{l}\text { Lama } \\
\text { Fermenta } \\
\text { si (jam) }\end{array}$ & $\begin{array}{l}\text { Jenis } \\
\text { starter }\end{array}$ & $\begin{array}{l}\text { Kadar } \\
\text { Protein } \\
(\%)\end{array}$ & $\begin{array}{c}\text { Kadar Gula } \\
\text { Total (\%) }\end{array}$ & $\begin{array}{c}\text { Kadar } \\
\text { Lemak (\%) }\end{array}$ & $\begin{array}{c}\text { Total } \\
\text { Asam (\%) }\end{array}$ & $\begin{array}{l}\text { Jumlah BAL } \\
\text { (log Cfu/ml) }\end{array}$ \\
\hline \multirow{3}{*}{4 jam } & St & $11,95^{\mathrm{cd}}$ & $20,24^{b c}$ & $0,245^{\mathrm{d}}$ & $0,88^{b c}$ & $7,40^{a}$ \\
\hline & $L b$ & $7,82^{\mathrm{abc}}$ & $21,12^{\mathrm{bcd}}$ & $0,050^{\mathrm{bc}}$ & $0,93^{\mathrm{C}}$ & $7,20^{a}$ \\
\hline & $S t-L b$ & $3,30^{a}$ & $15,16^{\mathrm{a}}$ & $0,120^{C}$ & $0,83^{b}$ & $7,75^{\mathrm{a}}$ \\
\hline \multirow{3}{*}{$6 \mathrm{jam}$} & St & $8,93^{\mathrm{bcd}}$ & $19,05^{b}$ & $0,075^{b}$ & $0,84^{\mathrm{bc}}$ & $7,50^{\mathrm{a}}$ \\
\hline & $L b$ & $10,24^{\text {bcd }}$ & $21,42^{\mathrm{bcd}}$ & $0,040^{\mathrm{bc}}$ & $0,87^{\mathrm{DC}}$ & $7,50^{\mathrm{a}}$ \\
\hline & $S t-L b$ & $4,91^{\mathrm{ab}}$ & $19,32^{b}$ & $0,075^{b}$ & $0,68^{\mathrm{a}}$ & $7,70^{a}$ \\
\hline \multirow{3}{*}{8 jam } & St & $6,41^{\mathrm{ab}}$ & $22,80^{\text {cd }}$ & $0,025^{\mathrm{a}}$ & $0,82^{b}$ & $7,40^{\mathrm{a}}$ \\
\hline & $L b$ & $13,56^{\mathrm{d}}$ & $19,32^{b}$ & $0,060^{b c}$ & $0,82^{b}$ & $7,35^{\mathrm{a}}$ \\
\hline & $S t-L b$ & $9,13^{\mathrm{bcd}}$ & $23,27^{d}$ & $0,050^{b c}$ & $0,59^{a}$ & $7,40^{a}$ \\
\hline
\end{tabular}

Keterangan: Kolom dengan notasi berbeda, menunjukkan beda nyata pada pengujian taraf signifikansi $5 \%$ 


\subsection{Kadar Protein Yoghurt Biji Ketapang \\ Hasil uji anova (Tabel 2)} menunjukkan bahwa kadar protein yoghurt susu biji ketapang pada perlakuan lama fermentasi tidak berbeda nyata, namun pada perlakuan jenis starter dan interaksi antara perlakuan lama fermentasi dan jenis starter menunjukkan adanya beda nyata. Kadar protein yang paling besar adalah 13,56 $\mathrm{g} / 100 \mathrm{~g}$ yang diperoleh dari perlakuan penggunaan jenis starter yaitu $L b$ dengan lama fermentasi 8 jam, sedangkan kadar protein terendah sebesar $3,3 \%$ yang diperoleh dari perlakuan penggunaan jenis starter yaitu St-Lb dengan lama fermentasi 4 jam. Kadar protein yang terkandung dalam yoghurt sudah memenuhi syarat mutu yoghurt SNI 2981-2009 yaitu 2,7 g/100 g. L. bulgaricus mampu mendegradasi protein yang menghasilkan enzim protease sehingga pada penggunaan bakteri ini kadar protein mengalami peningkatan seperti yang ditunjukkan dalam Tabel 2. Hafsah dan Astriana (2012) dalam penelitiannya menyatakan bahwa $L$. bulgaricus lebih baik dalam memfermentasi susu. $S$. thermophilus berperan terlebih dahulu dalam menurunkan $\mathrm{pH}$ hingga sekitar 5,0 dan kemudian dalam keadaan asam ini digunakan oleh L. bulgaricus untuk menurunkan $\mathrm{pH}$ hingga mencapai 4,0. Selain itu beberapa zat hasil fermentasi mikroorganisme yang berperan dalam menentukan rasa produk adalah asam laktat, asetaldehida, asam asetat, dan diasetil (2,3-butana diona) (Ramadhan, 2016). Baik dan tidaknya fermentasi yoghurt dapat ditandai dengan adanya produksi asam atau protein.

\subsection{Gula Total}

Hasil uji anova menunjukkan bahwa kadar gula total yoghurt susu biji ketapang pada perlakuan lama fermentasi dan interaksi antara lama fermentasi dengan jenis starter terdapat beda nyata namun pada perlakuan jenis starter tidak menunjukkan adanya beda nyata. Kadar gula total yang paling besar adalah 23,27 $\mathrm{g} / 100 \mathrm{~g}$ yang diperoleh dari perlakuan penggunaan jenis starter yaitu $S t-L b$ dengan lama fermentasi 8 jam, sedangkan kadar gula total terendah sebesar 19,05 $\mathrm{g} / 100 \mathrm{~g}$ yang diperoleh dari perlakuan penggunaan jenis starter yaitu St dengan lama fermentasi 6 jam. Lama fermentasi berpengaruh terhadap kadar gula yoghurt dimana untuk $S$. thermophilus dan $S$. thermophilus- $L$. bulgaricus dalam lama fermentasinya mengalami kenaikan jumlah gula sedangkan untuk $L$. bulgaricus mengalami penurunan. Kandungan karbohidrat terhitung sebagai serat biji ketapang sebesar 13,16 g/100 $\mathrm{g}$ menyebabkan total gula dari yoghurt tinggi. Semakin banyak bakteri asam laktat yang terbentuk maka semakin banyak sumber gula yang digunakan selama metabolisme (Stanburry, Whitaker \& Hall, 1994).

\subsection{Kadar Lemak}

Kadar lemak yoghurt susu biji ketapang dengan perlakuan lama fermentasi, jenis starter dan interaksi antara jenis starter dengan lama fermentasi menunjukkan adanya beda nyata. Kadar lemak paling tinggi didapatkan dari perlakuan jenis starter $S t$ dengan lama fermentasi 4 jam yaitu $0,245 \mathrm{~g} / 100 \mathrm{~g}$, sedangkan untuk kadar lemak yang paling rendah didapatkan dari perlakuan jenis starter St dengan lama fermentasi 8 jam yaitu $0,025 \mathrm{~g} / 100 \mathrm{~g}$. Setiap jenis starter memberikan pengaruh yang berbeda pada setiap lama fermentasinya dimana $S$. thermophilus dapat menurunkan kadar lemak dalam yoghurt sedangkan $L$. bulgaricus tidak menunjukkan adanya kenaikan maupun penurunan yang signifikan selama fermentasi berlangsung. Namun, untuk kombinasi antara kedua bakteri tesebut dapat menurunkan kadar lemak dalam yoghurt.

\subsection{Total Asam}

Keasaman yoghurt susu biji ketapang dengan perlakuan lama fermentasi, jenis starter dan interaksi antara jenis starter dengan lama fermentasi menunjukkan adanya beda nyata. Tingkat keasaman yoghurt terendah pada perlakuan St-Lb dengan lama fermentasi 8 jam dengan angka $0,59 \%$. Tingkat keasaman tertinggi terdapat pada yoghurt dengan starter $L b$ 
dengan lama fermentasi 4 jam dengan angka $0,93 \%$. Tingkat keasaman dalam yoghurt sudah memenuhi syarat mutu yoghurt SNI 2981-2009 yaitu 0,5-2,0\%.

Setiap jenis starter yang digunakan menghasilkan keasaman yang berbeda $S$. thermophilus- $L$. bulgaricus akan menghasilkan suasana asam yang lebih rendah karena pada pembuatan yoghurt kedua bakteri ini saling bersimbiosis. Hasil degradasi protein oleh $S$. thermophilus yang menghasilkan asam format dan $\mathrm{CO}_{2}$ dapat menstimulir pertumbuhan $L$. bulgaricus dengan cepat. Kombinasi kedua kultur dalam yoghurt akan menghasilkan asam laktat lebih cepat jika dibandingkan dengana menggunakan salah satu kultur menurut Walstra (1999) dalam Prasetyo (2010).

Aktivitas BAL yang semakin rendah diasumsikan bahwa tingkat keasaman yang juga semakin rendah. Hal ini sesuai dengan pendapat Astawan (2008) dalam Kumalasari, Nurwantoro, \& Mulyani, (2012) yang menyatakan bahwa, proses fermentasi yoghurt pada prinsipnya yaitu menguraikan laktosa (gula susu) menjadi asam laktat dan berbagai komponen aroma dan citarasa. Laktosa yang semakin banyak dimakan oleh bakteri akan semakin mampu memproduksi asam laktat, maka semakin tinggi asam yang terbentuk.

\subsection{Total Bakteri Asam Laktat (BAL)}

Hasil penghitungan total bakteri pembentuk asam menunjukkan bahwa perlakuan lama fermentasi dan jenis starter maupun interaksi antara lama fermentasi dan jenis starter tidak menunjukkan adanya beda nyata. Total bakteri asam laktat pada minuman yoghurt susu biji ketapang didapat nilai log bakteri asam laktat berkisar antara 7,35-7,75 CFU/ml. Hasil analisa menunjukkan bahwa nilai log tertinggi dari total bakteri asam laktat sebesar 7,75 CFU/ml pada perlakuan St-Lb dengan lama fermentasi 4 jam sedangkan nilai log terendah sebesar 7,20 CFU/ml pada perlakuan $L b$ dan lama fermentasi 4 jam.

\section{KESIMPULAN DAN SARAN}

Penggunaan starter $L$. bulgaricus dengan lama fermentasi 8 jam menghasilkan yoghurt biji Ketapang dengan persentase protein tertinggi yaitu $13,56 \%$. Perlakuan jenis starter $S$. thermophilus dan $L$. bulgaricus dengan lama fermentasi 8 jam menghasilkan yoghurt biji Ketapang dengan kadar gula $23,27 \%$ dan total asam $0,59 \%$. Kadar lemak paling tinggi, yaitu $0,245 \%$ didapatkan dari perlakuan jenis starter $S$. thermophilus dengan lama fermentasi 4 jam. Menurut standar SNI Yoghurt tahun 2009, yoghurt tanpa perlakuan pemanasan setelah fermentasi sebaiknya mengandung protein minimal $2,7 \%$, lemak $3,0 \%$, dan tingkat keasaman antara 0,5-2,0\%. Untuk menghasilkan yoghurt biji ketapang dengan kadar protein yang tinggi, maka susu biji ketapang sebaiknya difermentasi selama 8 jam menggunakan starter $L$. bulgaricus. Total bakteri asam laktat pada minuman yoghurt biji ketapang nilai log bakteri asam laktat berkisar antara 7,35-7,75 log 10 $\mathrm{CFU} / \mathrm{ml}$.

\section{UCAPAN TERIMAKASIH}

Ucapan terima kasih diberikan kepada Yayasan Perguruan Tinggi Slamet Riyadi Surakarta yang telah memberikan pendanaan atas penelitian ini.

\section{DAFTAR PUSTAKA}

AOAC. (2000). Official Methods of Analysis. 17th Edition, The Association of Official Analytical Chemists, Gaithersburg, MD, USA. Methods 925.10, 65.17, 974.24, 992.16.

Astawan, M. (2008). Sehat dengan hidangan hewani. Jakarta: Penebar Swadaya.

Budi, A. C. (2016). Pemanfaatan biji ketapang (Terminalia catappa) sebagai bahan dasar tahu dengan substitusi kacang kedelai dan bahan penggumpal asam cuka dan batu tahu untuk meningkatkan ketahanan pangan (Skripsi Sarjana). Universitas Negeri Semarang, Semarang. 
Ginting, N., \& Pasaribu, E. (2005). Pengaruh temperatur dalam pembuatan yoghurt dari berbagai jenis susu dengan menggunakan Lactobacillus bulgaricus dan Streptococcus thermophilus. Jurnal Agribisnis Peternakan, 1(2), 73-77. https://doi.org/10.2118/36502-ms

Hadiwiyoto, S. (1983). Teori dan prosedur mutu susu dan hasil olahannya. Yogyakarta: Liberty.

Hafsah, \& Astriana. (2012). Pengaruh variasi starter terhadap kualitas yoghurt susu sapi. Jurnal Bionature, 13(2), 96-102.

Jaya, F., Kusumahadi, D., \& Amertaningtyas, D. (2011). Pembuatan minuman probiotik (yoghurt) dari proporsi susu sapi dan kedelai dengan isolat Lactobacillus casei dan Lactobacillus plantarum. Jurnal IImu Dan Teknologi Hasil Ternak, 6(1), 13-17.

Kumala, N. T., Setyaningsih, R., \& Susilowati, A. (2004). Pengaruh konsentrasi susu skim dan madu terhadap kualitas hasil yogurt kedelai (Glycine max ( L .) Merr .) dengan Inokulum Lactobacillus casei. Bio Smart, 6(1), 15-18.

Kumalasari, K. E. D., Nurwantoro, \& Mulyani, S. (2012). Pengaruh kombinasi susu dengan air kelapa terhadap total Bakteri Asam Laktat (BAL), total gula dan keasaman drink yoghrut. Jurnal Aplikasi Teknonlogi Pangan, 1(2), 48-53.

Maghfiroh, Wijaya, A. A., Sa"adah, E., Valla, M. I. A., \& Romadhon, F. (2014). Karakteristik sensori susu ketapang (Terminalia catapa L .) substitusi susu kedelai high protein. Agrointek, 8(2), 69-74.

Muawanah, A. (2007). Pengaruh lama inkubasi dan variasi jenis starter terhadap kadar gula, asam laktat, total asam dan $\mathrm{pH}$ yoghurt susu kedelai. Jurnal Kimia VALENSI, 1(1), 1-6. https://doi.org/10.15408/jkv.v1i1.206

Pichot, R. (2010). Stability and characterisation of emulsions in the presence of colloidal particles and surfactants. School of Engineering,
The University of Birmingham.

Prasetyo, H. (2010). Pengaruh penggunaan starter yoghurt pada level tertentu terhadap karakteristik yoghurt yang dihasilkan (Skripsi Sarjana). Fakultas Pertanian, Universitas Sebelas Maret, Surakarta.

Ramadhan, F. (2016). Pengaruh konsentrasi susu skim dan suhu fermentasi terhadap karakteristik yoghurt kacang koro (Canavalia Ensiformis L) (Skripsi Sarjana). Fakultas Teknik, Universitas Pasundan, Bandung.

Sayuti, I., Wulandari, S., \& Sari, K. (2013). Efektivitas penambahan ekstrak ubi jalar ungu (Ipomoea batatas var. Ayamurasaki) dan susu skim terhadap kadar asam laktat dan $\mathrm{pH}$ yoghurt jagung manis (Zea mays L. Saccharata) dengan menggunakan inokulum Lactobacillus acidophilus dan Bifidobacterium sp. Biogenesis, 9(2), 21-27. https://doi.org/10.1017/CBO97811074 15324.004

Sholeha, F. (2018). Kualitas gizi tempe dari biji ketapang (Terminalia catappa) dengan perbedaan waktu fermentasi (Skripsi Sarjana). Universitas Islam Negeri Raden Intan, Lampung.

Sofawati, D. (2012). Uji aktivitas antidiabetes fraksi-fraksi buah ketapang (Terminalia catappa L.) dengan metode penghambatan aktivitas alpha glukosidase dan identifikasi golongan senyawa kimia dari fraksi yang aktif (Skripsi Sarjana). Universitas Indonesia, Jakarta.

Stanburry, P.F., Whitaker, A., \& Hall, S.J. (1994). Principles of fermentation technology. $2^{\text {nd }}$ Edition, MPG Books Ltd. Bodwin, Cornwall, England.

Sudarmadji, S., Haryono, B., \& Suhardi. (1997). Prosedur analisis pangan dan hasil pertanian. Yogyakarta: Liberty.

Suhartatik, N., Widanti, Y. A. W., \& Anwar, S. (2018). Yoghurt susu wijen dengan pewarna alami ekstrak buah naga merah. Media IImiah Teknologi Pangan, 5(1), 43-48.

Sumarni, S., Mazakkar, M. Z., \& Tamrin. (2017). Pengaruh penambahan CMC 
(Carboxy Methyl Cellulose) terhadap karakteristik organoleptik, nilai gizi dan sifat fisik susu ketapang (Terminallia catappa L .). J. Sains Dan Teknologi Pangan, 2(3), 604-614.

Utaminingrum, F. (2011). Pengaruh pemberian poghurt kedelai hitam (black soyghurt) terhadap kadar kolesterol LDL serum pada tikus dislipidemia (Skripsi Sarjana). Universitas Diponegoro, Semarang.

Widyaningsih, S., Chasani, M., Diastuti, H., \& Fredyono, W. (2018). Liquid soap from nyamplung seed oil (Calophyllum inophyllum L.) and ketapang (Terminalis catappa L.) as antioxidant and cardamom (Amomum compactum) as fragrance. Molekul, 13(2), 172-179. https://doi.org/10.20884/1.jm.2018.13. 2.461

Zain, W. N. H. dan B. K. (2017). Karakteristik mikrobiologis dan fisik yogurt susu kambing dengan penambahan probiotik Lactobacillus Acidophilus. Jurnal IImiah IImu-ilmu Peternakan, 20 (1), 1-8. 